Abbreviated Key Title: Sch J Agric Vet Sci

ISSN 2348-8883 (Print) | ISSN 2348-1854 (Online)

Journal homepage: https://saspublishers.com

\title{
Study of Air-Spora over the Groundnut Fields in Nashik District of Maharashtra, India
}

Malati H. Aher

Head, Department of Botany, K. R. A. College Deola, Nashik, Maharashtra, India

DOI: $10.36347 /$ sjavs.2021.v08i02.003

| Received: 04.02.2021 | Accepted: 15.02.2021 | Published: 21.02.2021

*Corresponding author: Malati $\mathrm{H}$. Aher

\section{Abstract}

Original Research Article

Air contains number of different particles suspended in it. Fungal spores, pollen grains, viruses, bacteria, dust particles, insect parts etc. The Present aerobiological investigation was carried out at Nashik District by using a device Tilak Air sampler. Continuous air monitoring operation was done for 97 days during the months of June, July, August and September of Kharif Season during the year 2013. Airborne catches trapped over the groundnut (Arachis hypogea L.) field includes 45 fungal spores, hyphal fragments, insect parts, pollen grains etc. the article defines the definite correlation between the air borne microorganisms, meteorological parameters, growth stages of the crop plants and their impact in bringing about the disease incidence to the ground nut crop plants. A volumetric Tilak Air Sampler was used to trap airborne biological components, which incidentally provided continuous quantitative and qualitative data. Present investigation also mainly aimed to study the population of fungal morphotypes prevailing in the ambient air over the groundnut fields in one Kharif Crop season.

Keywords: Tilak air sampler, Groundnut crop, Air-spora, Kharif season.

Copyright $\odot$ 2021: This is an open-access article distributed under the terms of the Creative Commons Attribution license which permits unrestricted use, distribution, and reproduction in any medium for non-commercial use (NonCommercial, or CC-BY-NC) provided the original author and source are credited.

\section{INTRODUCTION}

Aerobiology is a scientific and multidisciplinary approach focused on the transport of organisms and biologically significant materials. Aerobiology thus does not simply mean the study of microorganisms in the atmosphere. Groundnut (Arachis hypogea L.) is an important food and oil seed crop in tropical and subtropical regions. It is native to South America, where, the genus Arachis is distributed over a wide range of environment from South of the Amazon to $34^{0} \mathrm{~s}$ altitude and from the eastern coast to the eastern slopes of the Andes [1] Groundnut crop as the world's fourth most important source of edible oil and important source of vegetable protein. Oil seeds account of groundnut is for one ninth (1/9) of the total agricultural production in India. Groundnut oil is used for cooking, used for production of vanaspati ghee, making shaving cream, used as lubricant. It can be eaten raw, roasted or used in different recipes. After harvesting Arachis hypogaea L. plants are used as fodder to cattle. Oil cake is a by-product formed after extraction of oil from seed is rich in protein and used as cattle feed and fertilizer for many crops. Groundnut crop is susceptible to a many kind of soil borne, seed borne and air borne diseases caused by fungi, viruses, bacteria and nematodes results into low yield of kernel $\&$ poor quality of fruits. Some of the important and major fungal diseases of groundnut crop are early Root rot (Macrophomina phaseolina), Viral disease are Rosette (Groundnut rosette assistor virus), leaf spot (Cercospora arachidicola), Rust disease (Puccinia arachidis), Collar rot or seedling blight (Aspergillus niger), Groundnut bud necrosis disease (Groundnut bud necrosis virus), late leaf spot (Cercospora personata) however during present investigation more trace has been given to the fungal components of airspora. Deshpande et al., [2] study the airspora of groundnut crop field. Sreeramulu \& Seshavataram 1962 [3], Sreeramulu and Ramalingam [4, 5]; Sreeramulu and Vittal [6, 7]; Tilak et al., [8] and onwards etc. were involved in the aerobiology and studied the aerospora over groundnut crop, Paddy crop, sunflower crop, cotton crop in different regions of India.

They have categorized in to five respective groups. Out of 45 air borne components, 5 belonged to Zygomycotina, 10 to Ascomycetes, 2 to Basidiomycetes, 21 to Deuteromycetes, and 3 included to other types. The percentage contribution of each spore type to the total airspora was calculated. The group Deuteromycetes was dominant with higherspore concentration $54.327 / \mathrm{m} 3$ of air and with 16.85 contribution, followed by Ascomycetes with spore concentration $84,140 / \mathrm{m} 3$ of air and $33.16 \%$ 
Malati H. Aher., Sch J Agric Vet Sci, Feb, 2021; 8(2): 15-19

contribution, then Basidiomycetes with spore concentration $23,968 / \mathrm{m} 3$ of air and $9.45 \%$ contribution, then other types with $21,504 / \mathrm{m} 3$ with $8.48 \%$ contribution, then Phycomycetes with $13,986 / \mathrm{m} 3$ of air with $5.51 \%$ contribution. Influence of weather factors such as humidity, rainfall, and temperature on the incidence of disease and percentage contribution of airborne components was also studied \& recorded. The information provided by this research study is useful for forecasting of the air borne diseases affecting the groundnut crop and to provide the effective control measures.

\section{MATERIALS AND METHODS}

The present aerobiological investigation involved qualitative and quantitative analysis of air spora over ground field at Nashik Dist. In Maharashtra state. Air monitoring survey was carried out by using Volumetric Tilak Air Sampler [9]. Tilak Air Sampler was installed in the centre of 1.62 hector area of a groundnut field and placed on the stool with its orifice facing west and at constant height of 2 feet above the ground level. Tilak Air Sampler is an electrically operated device which has a rotatory drum. The drum completes one rotation in eight days. Acellophane tape has one surface sticky, wrapped around the drum while other surface was smeared with petroleum jelly as adhesive so as to stick spores. Continuous air was sampled at the rate of five (5) litters per minute for a kharif season of a year after each eight days when drum completed one rotation, previous cellophane tape was removed \& replaced by a new cellophane tape. A Cellophane tape was brought to the laboratory \& cut into 16 (sixteen) pieces of equal length. Each division provides a qualitative and quantitative data of airborne bio-components of day \& night. The slides were prepared and scanned. Air sampling was initiated eight days prior to the sowing of seeds of groundnut in the experimental field and continued eight days even after harvesting the crop. The daily record of meteorological data was regularly maintained with the help of digital thermometer and hygrometer and rain fall record was obtained from.

In the present study, the crop cultivated was Groundnut (Arachis hypogea L.) Var.JL24 1.62ha. Land area was devoted for cultivation of ground nut for one consecutive Kharif Seasons i.e. First Kharif season from 23 June 2013 to 20 September 2013 Air sampling was initiated eight days prior to the sowing of seeds of groundnut in the experimental fields and continued for eight days even after its harvesting the same crop. The daily meteorological data of temperature, relative humidity ad rainfall was maintained as obtained from Metrological Department, Peth Road, Peth Phata, Nashik.

Table-1: Reveals Total Airspora and Its Percentage Contribution to The Total Airspora of one Kharif Seasons Over Groundnut Field from 23 June 2013 to 20 September 2013

\begin{tabular}{|c|c|c|c|}
\hline \multirow[t]{2}{*}{ Sr. No } & \multirow[t]{2}{*}{ Spore type } & \multicolumn{2}{|l|}{ First Kharif Season } \\
\hline & & Spore Conc. $/ \mathrm{m}^{3}$ of air & $\%$ Contribution \\
\hline A) & ZYGOMYCOTINA & & \\
\hline 1 & Albugo & 1174 & 0.20 \\
\hline 2 & Cunninghamella & 2813 & 0.48 \\
\hline 3 & Mucor & 6104 & 1.04 \\
\hline 4 & Phytophthora & 1537 & 0.26 \\
\hline \multirow[t]{2}{*}{5} & Rhizopus & 11150 & 1.91 \\
\hline & Total & 22778 & 3.89 \\
\hline B) & ASCOMYCOTINA & & \\
\hline 1 & Amphisphaerella & 2885 & 0.49 \\
\hline 2 & Bombardia & 2131 & 0.36 \\
\hline 3 & Chaetomium & 18125 & 3.11 \\
\hline 4 & Claviceps & 5945 & 1.02 \\
\hline 5 & Cucurbitaria & 4741 & 0.81 \\
\hline 6 & Didymosphaeria & 783 & 0.13 \\
\hline 7 & Hysterium & 27637 & 4.75 \\
\hline 8 & Melanospora & 16182 & 2.78 \\
\hline 9 & Pleospora & 9642 & 1.65 \\
\hline \multirow[t]{2}{*}{10} & Sordaria & 10222 & 1.75 \\
\hline & Total & 98293 & 16.85 \\
\hline $\mathbf{C}$ & BASIDIOMYCOTINA & & \\
\hline 1 & Basidiospores & 4886 & 0.84 \\
\hline \multirow[t]{2}{*}{2} & Smutspores & 16936 & 2.91 \\
\hline & Total & 21822 & 3.75 \\
\hline
\end{tabular}


Malati H. Aher., Sch J Agric Vet Sci, Feb, 2021; 8(2): 15-19

\begin{tabular}{|c|c|c|c|}
\hline D & DEUTEROMYCOTINA & & \\
\hline 1 & Alternaria & 34452 & 5.92 \\
\hline 2 & Aspergillus & 6974 & 1.19 \\
\hline 3 & Beltrania & 17733 & 3.05 \\
\hline 4 & Bispora & 31436 & 5.40 \\
\hline 5 & Ceratophorum & 2943 & 0.50 \\
\hline 6 & Cercospora & 16196 & 2.78 \\
\hline 7 & Cladosporium & 14140 & 2.43 \\
\hline 8 & Curvularia & 27734 & 4.77 \\
\hline 9 & Clasterosporium & 1358 & 0.23 \\
\hline 10 & Dictyoarthrinium & 42 & 0.007 \\
\hline 11 & Dictyosporium & 294 & 0.05 \\
\hline 12 & Diplodia & 17850 & 3.07 \\
\hline 13 & Epicoccum & 12166 & 2.09 \\
\hline 14 & Exosporium & 6972 & 1.19 \\
\hline 15 & Fusarium & 20776 & 3.57 \\
\hline 16 & Helminthosporium & 27020 & 4.64 \\
\hline 17 & Heterosporium & 11900 & 2.04 \\
\hline 18 & Hirudinaria & - & - \\
\hline 19 & Harknessia & 3444 & 0.59 \\
\hline 20 & Memnonniella & 9842 & 1.69 \\
\hline 21 & Nigrospora & 15778 & 2.71 \\
\hline 22 & Pestalotia & 10290 & 1.76 \\
\hline 23 & Pithomyces & 17192 & 2.95 \\
\hline 24 & Pyricularia & 1652 & 0.28 \\
\hline 25 & Sirodesmium & 6762 & 1.16 \\
\hline 26 & Sporothirx & 616 & 0.10 \\
\hline 27 & Tetraploa & 462 & 0.07 \\
\hline \multirow[t]{2}{*}{28} & Trichocladium & 532 & 0.09 \\
\hline & Total & 316556 & $\mathbf{5 4 . 3 2 7}$ \\
\hline $\mathbf{E}$ & OTHER TYPES & & \\
\hline 1 & Hyphal fragments & 3430 & 0.72 \\
\hline 2 & Insect parts & 2828 & 0.60 \\
\hline \multirow[t]{3}{*}{3} & Pollen grains & 5152 & 1.08 \\
\hline & Total & 11410 & 2.40 \\
\hline & Grand Total & 474956 & 100 \\
\hline
\end{tabular}

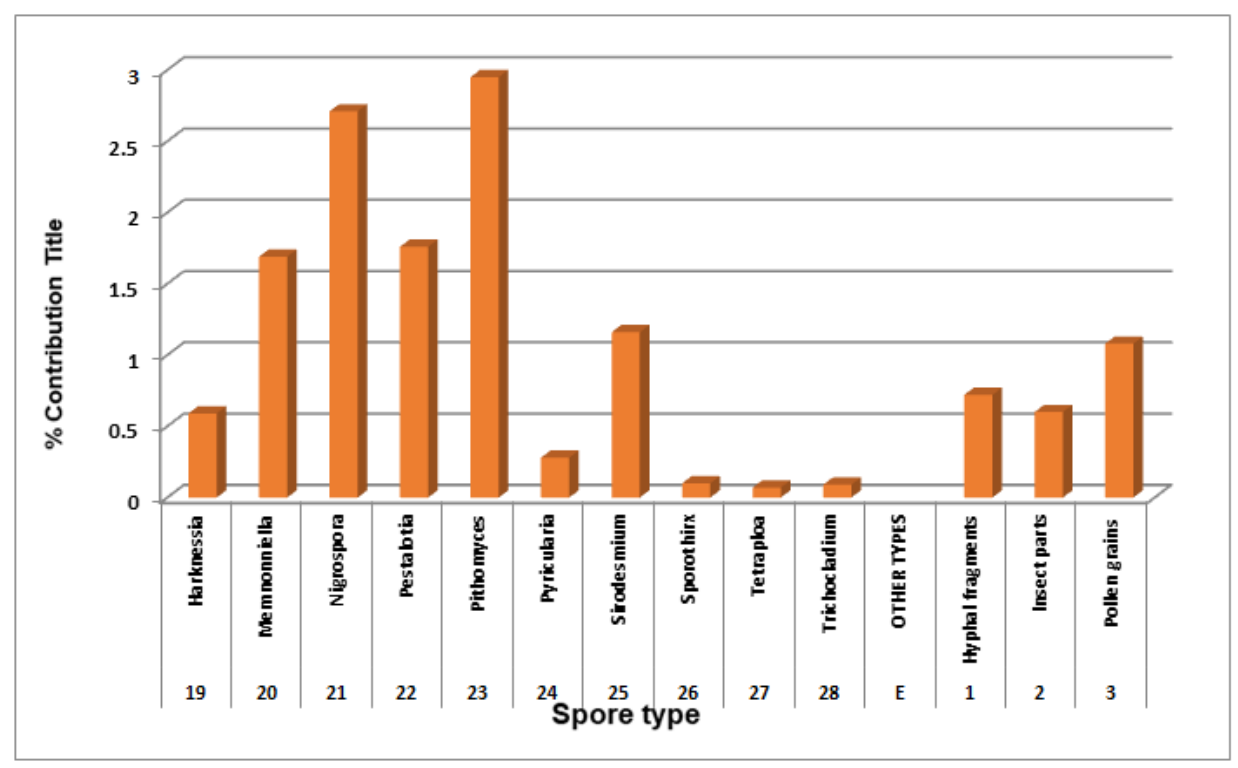

Graph-1 
Table-2

\begin{tabular}{|l|l|}
\hline Spore Groups & \% Contribution \\
\hline Deuteromycotina & 54.327 \\
\hline Ascomycotina & 16.85 \\
\hline Zygomycotina & 3.89 \\
\hline Basidiomycotina & 3.75 \\
\hline Other Types & 2.4 \\
\hline
\end{tabular}

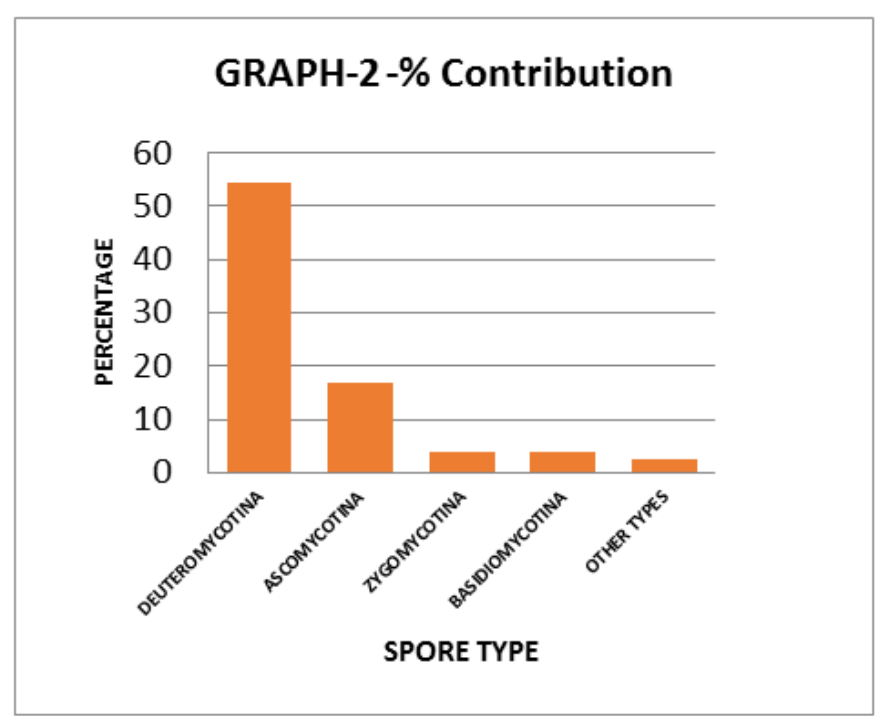

Graph-2: Percentage Contribution of total spores' types of each group in Kharif Season during the year 2013

\section{RESULT AND DISCUSSION}

The slides were observed and identification of fungal spore carried out with the help of visual identification, comparing with permanent slides and available literature of aerobiology and the result of the analysis given in table The present aerobiological investigation for Kharif season of the year have revealed total forty-five airborne components of these fourty-five (45) is fungal air borne bio components and are classified in to four groups such as Phycomycetes includes three (3) spore types, Ascomycetes contributes twenty two (22) spore types, Basidiomycetes contributed total four (4) spore types and deuteromycetes contributed total twenty one (21) spore types. The remaining five (5) airborne components forms artificial group and are belonged to other type.

It is observed that temp. Humidity growth and age of plant favour the incidence and spread of disease. During the month of July Rhizopus member of group Zygomycotina contributed to the total airspora by contributing $3.53 \%$ conc. $/ \mathrm{m}^{3}$ of air. Concentration of this spore was continuous throughout the investigation maximum percentage of spore observed during the month of July.

Chaetomium member of Ascomycotina contributed $3.00 \%$ conc. $/ \mathrm{m}^{3}$ to the total airspora over the crop field during the month of September.

Smut spores belong to Basidiomycotina are having maximum percentage that is $5.39 \%$ conc. $/ \mathrm{m}^{3}$ during the month of August. Which shows the possibilities of the increase in the percentage of occurrence disease. It is alarming situation for the grower.

Alternaria $\quad 6.65 \%$ conc. $/ \mathrm{m}^{3} \quad$ (July), Bispora $6.10 \%$ conc. $/ \mathrm{m}^{3}$, Tilak [10], Mullaiah [11] and Aher et al., [12] have clearly brought out the close relationship between the spore load of pathogen in air, meterological factors growth stages of the crop are related with each other. Climatic factors were favorable for initiation of the disease but the crop variety grown in the field (Arachis hypogaea L.) JL-24 was found to be highly resistant for disease incidence during the periods when the crop was growing in the fields and therefore crop was found quite healthy during this investigation period.

\section{REFERENCES}

1. Gregory RL. Perceptions as hypotheses. Philosophical Transactions of the Royal Society of London. B, Biological Sciences. 1980 Jul 8;290(1038):181-97.

2. Deshpande N, Jensen V, Bulbrook RD, Berne T, Ellis F. Accumulation of tritiated oestradiol by human breast tissue. Steroids. 1967 Sep $1 ; 10(3): 219-32$.

3. Sreeramulu T, Seshavataram V. Spore content of air over paddy fields. I. Changes in a field near Pentapadu from 21 September to 31 December 1957. Indian Phytopath. 1962;15:61-74. 
4. Sreeramulu T, Ramalingam A. Spore Content of Air over Paddy Fields. 2. Changes in a Field Near Visakhapatnam From November 3, 1959 To January 9, 1960. Proceedings of the National Academy Of Sciences India Section B-Biological Sciences. 1963 Jan 1;33(3):423.

5. Sreeramulu T, Ramalingam A. A two-year study of the air-spora of a paddy field near Visakhapatnam. 1966.

6. Sreeramulu T, Vittal BP. Periodicity in the airborne spores of the rice false smut fungus, Ustilaginoidea virens. Transactions of the British Mycological Society. 1966 Sep 1;49(3):443-9.

7. Sreeramulu T, Vittal BP. Periodicity in the uredospore content of air within and above a sugarcane field. Indian Bot Soc J. 1971.
8. Tilak ST, Srinivasulu BV. Air-spora of Aurangabad. Indian Journal of Microbiology. 1967;7(4):167-9.

9. Tilak ST, Kulkarni RL. A new air sampler. Experientia. 1970 Apr;26(4):443-4.

10. Tilak JB. Costs of education in India. International Journal of Educational Development. 1988 Jan $1 ; 8(1): 25-42$.

11. Mallaiah KV. Aerobiology of Cercospora Sp. Pathogenic to Crop plants. Recent researches in Ecology, Environment, and Pollution. 1989;3:6778.

12. Aher SK, Thite SV, Pande BN. Fungal air spora of a groundnut field. Eco Env and Cons. 2002; $8(3): 283-288$. 